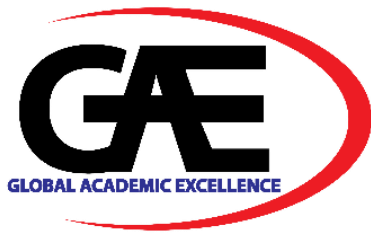

\title{
INTENTION TO ADOPT INFRASTRUCTURE AS-A SERVICE BASED E-LEARNING: DATA SCREENING AND PRELIMINARY ANALYSIS
}

\author{
Abubakar Magira Tom ${ }^{1 *}$, Wiwied Virgiyanti ${ }^{2}$, Wan Rozaini ${ }^{3}$ \\ 1 School of Computing, College of Arts \& Sciences, Universiti Utara Malaysia, Malaysia \\ Email: magiratom@gmail.com \\ 2 School of Computing, College of Arts \& Sciences, Universiti Utara Malaysia, Malaysia \\ Email: wiwied@uum.edu.my \\ 3 School of Computing, College of Arts \& Sciences, Universiti Utara Malaysia, Malaysia \\ Email: rozai174@uum.edu.my \\ Corresponding Author
}

\section{Article Info:}

\section{Article history:}

Received date: 03.03 .2020

Revised date: 27.04 .2020

Accepted date: 10.05 .2020

Published date: 10.09.2020

\section{To cite this document:}

Tom, A. M., Virgiyanti, W., \& Rozaini, W. (2020). Intention to Adopt Infrastructure As-A Service Based E-Learning: Data Screening and Preliminary Analysis. Journal of Information System and Technology Management, 5 (18), 01-17.

DOI: $10.35631 /$ JISTM.518001.

\begin{abstract}
:
The demand for providing education in developing countries' educational institutions is growing exponentially. Hence, the need for cloud-based elearning to provide effective and efficient e-learning content 24/7. This paper aims to provide a comprehensive step by step guide on the data cleaning procedures for evaluating the Intention to Adopt Infrastructure as-a ServiceBased E-learning among the ICT top managers. Four hundred fifty-four (454) respondents were derived from universities across the Northern region of Nigeria, using a systematic random sampling technique. Likewise, the exercise was performed to suit the multivariate analysis supposition. In light of that, the pilot study, missing data analysis, as well as factor analysis via the Exploratory Factor Analysis (EFA) were performed using the Statistical Package for Social Science (SPSS v. 25). The findings revealed that the data fulfilled the condition of multivariate analysis. Therefore, these results provide intuition to perform further statistical and hypotheses assessments.
\end{abstract}

Keywords:

Cloud Computing, E-Learning, Higher Education Institutions, Developing Countries, Data Cleaning, Nigeria

\section{Introduction}

Cloud computing (CC) is a prototype which permits resources to be provisioned via the web "as-a-Service". The "as-a-Service" refers to renting the resources and service of cloud to cloud 


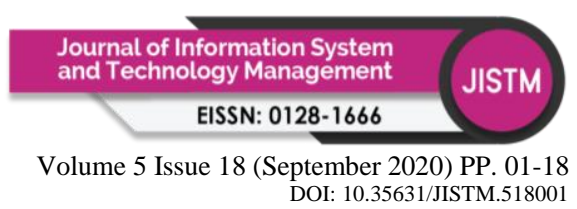

users on a pay-as-you-go method. The cloud is comprised of numerous deployment models which are; the "Infrastructure as a Service (IaaS), Platform as a Service (PaaS) as well as Software-as-a-Service (SaaS)" (Mell \& Grance, 2011). In addition, the service models include the "private, public, hybrid, and community" cloud. The Higher Education Institutions (HEIs) could draw numerous benefits from $\mathrm{CC}$ such as easy and quick access to resources, improving student performance, cost savings (operational costs) and availability of learning contents anywhere and anytime without geographical restrictions.

Nonetheless, its adoption in emerging nations and precisely Nigeria is limited. Furthermore, elearning alludes "to the environment in which student's relations with learning resources (readings, the assignment, exercise, etc.) peers, and or instructors are facilitated via innovative information technology" (Alavi \& Leidner, 2001, p. 2). The CC for e-learning is comprised of a collection of resources (like hardware, software, etc.) to augment the out-dated e-learning systems. Similarly, most of the existing research on CC for e-learning concentrates on the SaaS model of the cloud, thus overlooking the PaaS as well as IaaS models. Hence, this study focuses on the IaaS service delivery model by proposing an "Infrastructure as-a Service-Based Elearning" (IaaSBEL) model. The IaaSBEL is a type of CC where the e-learning systems are accommodated on the on-premise IaaS infrastructure and thus, can be subscribed to by the Nigerian HEIs in a pay-per-use approach. The reason for proposing IaaSBEL is its costeffectiveness, efficiency and effectiveness of delivering learning contents to users. Despite the ample benefits of the IaaSBEL infrastructure, its adoption in Nigeria is limited.

Furthermore, the importance of data screening cannot be overemphasized because it is essential in social science and IS research (Hair, Hult, Ringle, \& Sarstedt, 2013). Hence, the availability of noise or outliers in the dataset heavily distorts the quality and outcome of the research findings. Nonetheless, missing data usually occurs when some questions are purposely or coincidentally skipped. The idea, besides any data cleaning, is to reduce noise or clean the data. However, overlooking the data cleaning phase would result in distorted results though Tabachnick and Fidell (2007) suggested the ideal method of dealing with missing data is to omit it from the dataset, and thus, only when the dataset is huge.

Diversely, with massive data collection, editing is arduous or even impossible (Maiyaki \& Mouktar, 2011). On account of this, it is examining data via descriptive statistics utilising the SPSS. Thus, all concealed mistakes or errors can be easily uncovered (Hair, Black, Babin, \& Anderson, 2010; Hair et al., 2013). This study examines concerns related to data cleaning as well as preliminary analysis to attain error-free data as endorsed by Hair et al. (2010) and Hair et al. (2013). "Data cleaning, also called data cleansing or scrubbing, deals with detecting and removing errors and inconsistencies from data in order to improve the quality of data"(Rahm, Erhard, 2000, p. 3). Therefore, a holistic analysis of data screening and preparation for evaluating the intention to adopt IaaSBEL is crucial. This study tries to answer the questions of how to perform data screening or cleaning in the area of Cloud-Based e-learning (IaaSBEL) studies. Hence, the subsequent sections provide an indebt techniques and steps of ridding research data of noise.

\section{Literature Review}

The CC provides ample benefits to teachers and students alike, where access to learning content is readily available "as-a-Service", collaboration and sharing, reliability, and affordability by HEIs in developing countries. With the recent COVID-19 pandemic, many developing 
countries are facing economic challenges and the total stoppage of education, as in the case of Nigeria. This, coupled with the recession, has compelled many developing countries to halt education. Nonetheless, there is a lack of studies on the adoption of CC for e-learning in developing countries in general and Nigeria in specific (Tom, Virgiyanti, \& Rozaini, 2019). Hence, making the adoption of $\mathrm{CC}$ in HEIs as a viable solution towards addressing the problem as mentioned above.

Table 1: Summary of Studies on The Adoption of CC For E-Learning in Developing Countries

\begin{tabular}{|c|c|c|c|c|}
\hline Authors & Independent Variables & $\begin{array}{l}\text { Research } \\
\text { Design }\end{array}$ & Theories & Findings \\
\hline $\begin{array}{l}\text { Odeh et al. } \\
\text { (2017) }\end{array}$ & $\begin{array}{l}\text { Barriers: Resistance to } \\
\text { New Technology, } \\
\text { Security, Privacy, } \\
\text { Compatibility with In- } \\
\text { House Lack of Management } \\
\text { Awareness } \\
\text { Enablers: cost } \\
\text { effectiveness, ease to } \\
\text { use, decentralization, } \\
\text { management support }\end{array}$ & $\begin{array}{l}\text { Qualitative } \\
\text { research } \\
\text { design }\end{array}$ & $\begin{array}{l}\text { DOI } \\
\text { theory }\end{array}$ & $\begin{array}{l}\text { The findings } \\
\text { suggest that } \\
\text { academic and } \\
\text { technical experts } \\
\text { recommend the } \\
\text { adoption of CC in } \\
\text { HEI. }\end{array}$ \\
\hline $\begin{array}{l}\text { Shana and } \\
\text { Abulibdeh } \\
(2017)\end{array}$ & $\begin{array}{l}\text { IVs: Perceived Ease of } \\
\text { Use, Perceived Usefulness, } \\
\text { DVs: Behavior Intention to Use, } \\
\text { Actual Use }\end{array}$ & $\begin{array}{l}\text { Quantitative } \\
\text { research } \\
\text { design }\end{array}$ & $\begin{array}{l}\text { TAM } \\
\text { theory }\end{array}$ & $\begin{array}{l}\text { The findings } \\
\text { reveal that } \\
\text { Perceived Ease of } \\
\text { Use, affects the } \\
\text { Behavior } \\
\text { Intention. }\end{array}$ \\
\hline $\begin{array}{l}\text { Sabi et al. } \\
\text { (2018) }\end{array}$ & $\begin{array}{l}\text { IV: Observability, Results Demo } \\
\text { nstrability, } \\
\text { Relative Advantage, } \\
\text { Complexity, } \\
\text { Compatibility, Trialability, ICT } \\
\text { Infrastructure, Data } \\
\text { Security, Risks, } \\
\text { Upfront Cost } \\
\text { DVs: CC Adoption Decision, } \\
\text { CC Actual Usage }\end{array}$ & $\begin{array}{l}\text { Quantitative } \\
\text { research } \\
\text { design }\end{array}$ & $\begin{array}{l}\text { DOI } \\
\text { theory }\end{array}$ & $\begin{array}{l}\text { The findings } \\
\text { indicated that CC } \\
\text { adoption, CC usa } \\
\text { ge, observability, } \\
\text { result } \\
\text { demonstrability, } \\
\text { Socio- } \\
\text { Cultural, and } \\
\text { trialability are } \\
\text { significantly } \\
\text { supported }\end{array}$ \\
\hline $\begin{array}{l}\text { Almazroi } \\
\text { et al. (2016) }\end{array}$ & $\begin{array}{l}\text { IVs: Subjective Norm, } \\
\text { Image, Job Relevance, } \\
\text { Output Quality, Result } \\
\text { Demonstrability, Self- } \\
\text { Efficacy, Perceptions } \\
\text { of External Control, } \\
\text { Anxiety, Playfulness, Perceived } \\
\text { Usefulness, Perceived Ease of } \\
\text { Use } \\
\text { DV: Behavioral Intention }\end{array}$ & $\begin{array}{l}\text { Quantitative } \\
\text { Research } \\
\text { Design }\end{array}$ & $\begin{array}{l}\text { TAM } 3 \\
\text { theory }\end{array}$ & $\begin{array}{l}\text { The result } \\
\text { indicated } \\
\text { that perceived } \\
\text { usefulness and } \\
\text { perceived ease of } \\
\text { use are the central } \\
\text { deterrence of the } \\
\text { Behavioral } \\
\text { Intention to CC }\end{array}$ \\
\hline
\end{tabular}


Sabi et al. IVs: Complexity, Compatibility,

Tom,

Virgiyanti and Osman (2019) (2017)

\section{Relative}

Advantage, Trialability, Observa bility,

Result Demonstrable Economic

$\&$ Cost,

Risk, Data Security Awareness,

Socio-

cultural, Infrastructure, Ease of

Use, Usefulness, University Age,

University Sie, University

Location, Individual Age

DVs: Intention to Adopt CC,

Actual Usage of CC

Tom et al. IVs: Relative Advantage, (2019)
IVs: "Relative Advantage, Compatibility, Trust, Security, Cost Savings, Competitive

Quantitative
research
design

DOI and Socio-cultural TAM factors such as Theories result demonstrability, usefulness, and data security significantly impact their intention to adopt $\mathrm{CC}$ in the university

Quantitative
research
design

\author{
TOE and \\ DOI \\ Theories
} indicated that Relative advantage, Cost Savings, Competitive Pressure,
The findings "Service provider Support has a significant impact on the Intention to Adopt IaaSBEL in Nigerian HEIs". Quantitative TOE and DOI "The findings research indicate that design Pressure, Service Provider Support" DV: Intention to Adopt IaaSBEL
Theories Relative

Advantage, Cost Savings, "Service Provider Support, and Government Support are the key predictors of the Intention to Adopt IaaSBEL".

Table 1 shows the summary of studies on the adoption of Cloud-Based E-learning in developing countries, the theories utilised, research design and the outcomes of the findings. It can be noted that studies on the adoption of Cloud-Based E-learning in developing countries and Nigeria in specific are limited.

\section{Research Framework}

Information System (IS) comprises of numerous areas such as e-government, e-learning, IaaSBEL, etc. Therefore, in this section, the theoretical foundation and conceptualization of 


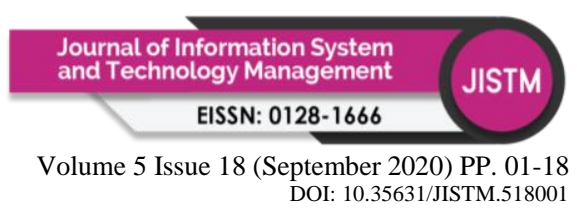

the IaaSBEL infrastructure were established based on the "Diffusion of Innovation (DOI) and Technology, Organization, Environment (TOE)" theories respectively (Rogers, 1995; Tornatzky \& Fleischer, 1990). For instance, the DOI, and TOE have been applied in numerous studies to establish technology adoption such as CC adoption (Tweel, 2012) RFID adoption (Wang et al., 2010) Broadband adoption (Chiu, Chen, \& Chen, 2017), e-government via CC adoption (Wahsh \& Dhillon, 2015), and CC in HEI adoption (Tariq et al., 2017) (Tom, Virgiyanti, \& Rozaini, 2019). The TOE framework accepts the insertion of other variables (Zhu \& Kraemer, 2005). On the other hand, the DOI has also been integrated with the TOE to complement the weakness of DOI (i.e. Environmental factors). Notwithstanding, both the DOI and TOE has shown good predictive power in the case of technology adoption decisions. The selected variables are derived from both DOI and TOE and some external constructs. The constructs are the "Relative Advantage, Compatibility, Trust, Security, Top Management Commitment, Cost Savings, Competitive Pressure, And Service Provider Support with Government Support" as a moderating variable, as depicted in Figure 1.

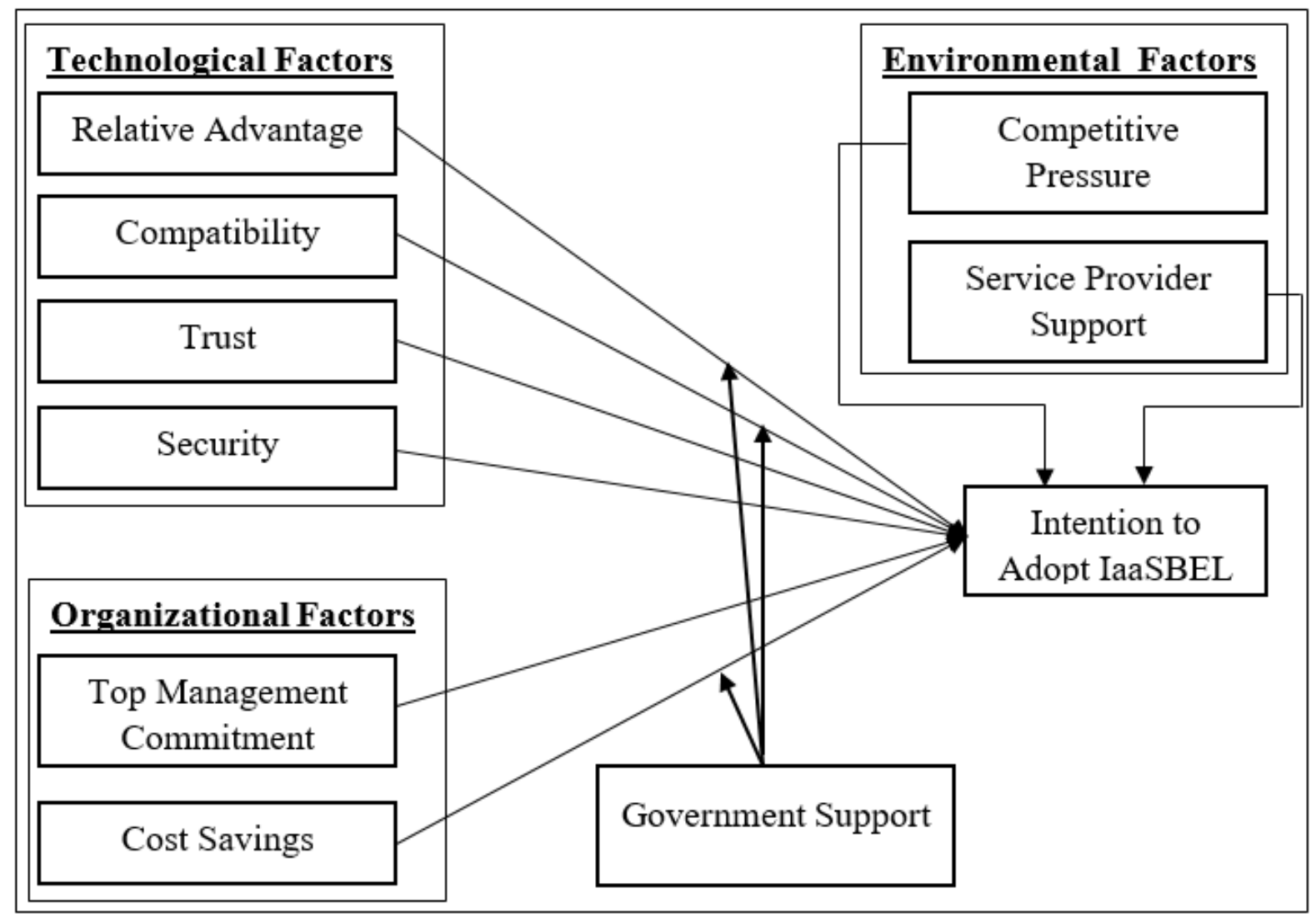

Figure 1: Research Framework

As shown in the above Figure 1, the variables were selected from the existing literature, where the variables were validated by experts from the Universiti Utara Malaysia. The TOE is the based theory and some variables of the DOI as well other external variables were used, to suit the study aim. The reason of doing the study is to understand why developing countries HEIs are still reluctant to adopting IaaSBEL, as well as providing 


\section{Research Methodology}

SPSS v. 25 was utilised for the descriptive as well as the inferential statistics. For example, "descriptive statistics, independent sample t-test, Mahalanobis distance, and correlation analysis" were utilised. The study's sample was derived from both the State and Federal universities within the Northern part of Nigeria, where the questionnaire was disseminated in a face to face manner. Disproportionate stratified random sampling and systematic random sampling were employed for the collection of data. The questionnaires were double of the sample size to lessen errors in sampling, response and nonresponse concerns (Blythe, 2005; Hair, Wolfinbarger, Ortinau, \& Bush, 2009). Because, if the sample size is small, the tendency of error is high (Alreck \& Settle, 1995) Hence, doubling the sample size is consistent with the studies conducted in Nigeria, to attain a minimum response of $50 \%$ of the questionnaires that were distributed (Mahmoud et al., 2018). Therefore, $227 * 2=454$ questions were distributed to the respondents. The outcomes of the questionnaires have yielded 248 returned, out of the 454 questionnaires that were disseminated to the target respondents.

\section{Measurement Scale}

Numerous studies have adopted/adapted items to measure the intention to adopt innovation in an organization. A thorough review of e-learning and cloud computing was conducted to create a pool of questions, which represents ten (10) variables, as shown in Table 2. Experts from Universiti Utara Malaysia (UUM) have validated and suggested some changes to ensure the operationalization, as well as the items (questions), are consistent. Therefore, all items are confirmed to measure the variables as operationalized.

Table 2: Variables Measurement

\begin{tabular}{ll}
\hline Construct & Sources \\
\hline Relative Advantage (RA) & (Ifinedo, 2011; Moore \& \\
& Benbasat, 1991; Oliveira et \\
& al., 2014) \\
\hline Compatibility (COM) & (Lai et al., 2014; \\
& Mohammed et al., 2018; \\
& Moore \& Benbasat, 1991) \\
\hline Trust (TR) & (Almazroi et al., 2016; \\
& Jarvenpaa et al., 2000; \\
& Pavlou, 2003; Wu, 2011a) \\
\hline Security (SEC) & (Mohammed et al., 2018; \\
& Wu, 2011) \\
\hline Top Management Commitment & (Ifinedo, 2011; Lai et al., \\
(TMC) & 2014; Oliveira et al., \\
& 2014; Premkumar \& \\
& Roberts, 1999) \\
\hline Cost Savings (CS) & (Gupta et al., 2013; Oliveira \\
& et al., 2014) \\
\hline Competitive Pressure (CP) & (Ansong et al., 2016; Ifinedo, \\
& 2011; Oliveira et al., 2014; \\
& Premkumar \& Roberts, \\
& 1999) \\
\hline Service Provider Support (SPS) & (Ifinedo, 2011; Klug \& Bai, \\
& 2014; Lai et al., 2014) \\
\hline
\end{tabular}




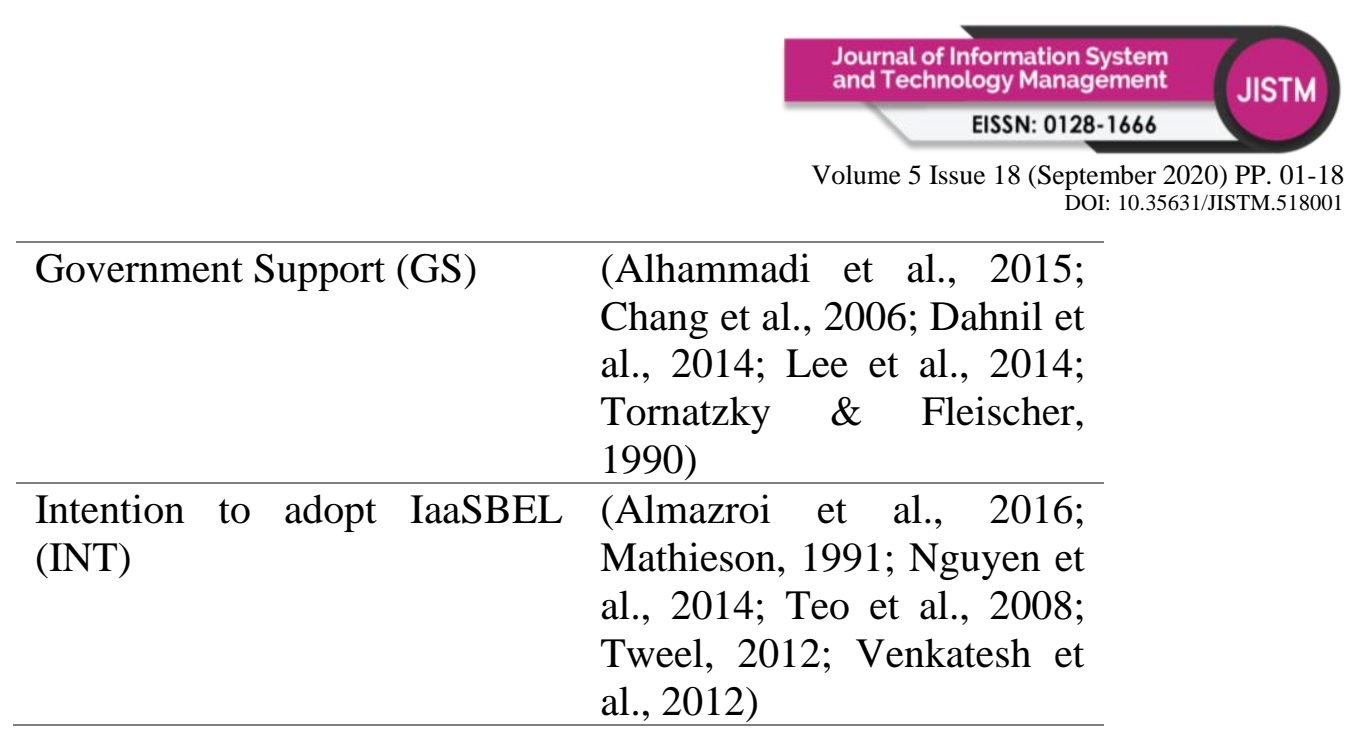

\section{Result and Discussion}

This section shows the results and discussion, out of the dispersed 454 questionnaires, 248 copies were retrieved, thus, giving a 54.6\% response rate. The response rate was slightly above $50 \%$, which was consistent with the expected rate of research conducted in Nigeria. Additionally, the researcher motivates the respondents by dashing out a pen, which, to an extent, encourages and creates a mutual understanding of the participants to answer the questionnaires. During the preliminary analysis stage, 1 item was deleted due to its low Cronbach's alpha. Similarly, from the 248 questionnaires, 38 were removed because a big part was not answered by the respondents. Fourteen (14) questionnaires were further removed due to lack of experience, and 10 removed during data cleaning, and 186 questionnaires were utilised for further analysis, which accounted for $40.9 \%$ valid responses as shown in Table 3. This exceeds the minimum survey response rate of 30\%, as postulated by Sekaran (2003) and Sekaran and Bougie (2010).

Table 3: Response Rate of Questionnaire

\begin{tabular}{ll}
\hline Response (s) & Frequency/Rate \\
\hline Number of distributed questionnaires & 454 \\
Returned questionnaires & 248 \\
Returned and usable questionnaires & 210 \\
Returned and excluded questionnaires & 14 \\
Deleted questionnaire during data cleaning & 10 \\
Questionnaires not returned & 206 \\
Usable Questionnaire & 186 \\
Response rate & $54.6 \%$ \\
Valid response rate & $40.9 \%$ \\
\hline
\end{tabular}

Table 3 presents the frequency of the number of questionnaires distributed, returned and usable questionnaire. In addition, the response rate, as well as the valid response rate (after data cleaning) is $40.9 \%$. 
Table 4: The Demographic Profile of Respondents

\begin{tabular}{llll}
\hline $\begin{array}{c}\text { Demographic } \\
\text { Profile }\end{array}$ & \multicolumn{1}{c}{ Category } & \multicolumn{1}{c}{$\begin{array}{c}\text { Frequency } \\
\text { (N=186) }\end{array}$} & $\begin{array}{c}\text { Percentage } \\
(\%)\end{array}$ \\
\hline Gender & Male & 137 & $73.7 \%$ \\
Education Level & Female & 49 & $26.3 \%$ \\
& Diploma & ----- & --- \\
& Bachelor's Degree & 48 & $25.8 \%$ \\
& Master's Degree & 119 & $64.0 \%$ \\
University & Doctorate & 19 & $10.2 \%$ \\
Position & Director & 17 & $9.0 \%$ \\
& Deputy Director & 17 & $9.0 \%$ \\
& Unit Head & 47 & $24.9 \%$ \\
Institution Type & 83 & $43.9 \%$ \\
Zone & Assistant Unit Head & 25 & $13.2 \%$ \\
& Dean & 108 & $57.1 \%$ \\
& Federal University & 81 & $42.9 \%$ \\
& North-East & 45 & $23.8 \%$ \\
& North-West & 86 & $45.5 \%$ \\
& North-Central & 58 & $30.7 \%$
\end{tabular}

University

$\mathrm{AD}(10 ; 5.4 \%) ; \mathrm{GM}(5 ; 2.7 \%) ; \mathrm{BC}(6 ; 3.2 \%) ; \mathrm{TR}(5 ; 2.7 \%) ; \mathrm{BN}$ $(6,3.2 \%) ; \mathrm{YB}(12 ; 6.2 \%)$; JG (11, 5.9\%); KD (13, 7.0\%); KN (20, $10.8 \%)$; KT (13, 7.0\%); KB (12, 6.5\%); SK (11, 5.9\%); ZF (6, 3.2\%); $\mathrm{AB}(5,2.7 \%) ; \mathrm{BN}(8,4.3 \%) ; \mathrm{KG}(9,4.8 \%)$; KW (12, 6.5\%); NS (8, $4.3 \%)$; NG (7, 3.8\%); PL (7, 3.8\%)

$\begin{array}{llll}\text { e-learning } & \text { None } & ---- & ----- \\ \text { experience } & \leq 1 \text { Year } & 10 & 5.4 \% \\ & \text { 1-2 Years } & 54 & 29.0 \% \\ & \text { 2-3 Years } & 86 & 46.2 \% \\ & \text { 4-5 Years } & 32 & 17.2 \% \\ & >\text { 5 Years } & 4 & 2.2 \% \\ \text { Cloud-based } & \text { Yes } & 189 & 100.0 \% \\ \text { e-learning } & \text { No } & ---- & ---- \\ \text { Experience } & \text { Microsoft Azure } & 68 & 36.6 \% \\ \text { Familiarity with } & \text { Amazon Web Service } & 96 & 51.6 \% \\ \text { Cloud-Based } & \text { Google GCP } & 22 & 11.8 \% \\ \text { e-learning } & \text { Others (Specify) } & ---- & ---- \\ & \text { None } & ---- & ---- \\ \text { Student } & <5000 & 6 & 3.2 \% \\ \text { Population } & 5,000-10,000 & 65 & 34.0 \% \\ & 10,000-20,000 & 13 & 7.0 \% \\ & 20,000-30,000 & 88 & 47.3 \% \\ & >30,000 & 14 & 7.5 \%\end{array}$

"AD = Adamawa; $\mathrm{GM}=$ Gombe; $\mathrm{BC}=$ Bauchi; TR; Taraba; $\mathrm{BN} ;$ Borno; $\mathrm{YB}=$ Yobe; JG = Jigawa; $\mathrm{KD}=$ Kaduna; $\mathrm{KN}=$ Kano; KT = Katsina; KB = Kebbi; $\mathrm{SK}=$ Sokoto; $\mathrm{ZF}=$ Zamfara; $\mathrm{AB}=$ Abuja; $\mathrm{BN}=$ Benue; $\mathrm{KG}=$ Kogi; $\mathrm{KW}=$ Kwara; $\mathrm{NS}=$ Nassarawa; $\mathrm{NG}=$ Niger; $\mathrm{PL}=$ Plateau" 


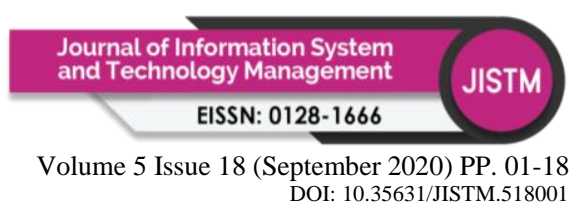

The descriptive analysis in Table 4 shows that $73.7 \%$ were male, and $26.3 \%$ were female. The categories of top managers show that $9.0 \%$ are directors, $9.0 \%$ are deputy directors, $24.9 \%$ are unit head, $43.9 \%$ are the assistant unit head, and $13.2 \%$ are deans respectively. Descriptive statistics show that the respondents were less than 1 year of experience at 5.4\%, 1-2 years, $29 \%, 2-3$ years, $46.2 \%, 4-5$ years $17.2 \%$, and above 5 years with $2.2 \%$ experience. This indicates that most of the respondents meet the experience level for this study. For the institution type, Federal universities have 57.1\%, whereas State universities have 42.9\%. For the familiarity with the cloud-based e-learning, 36.6\% are familiar with Microsoft Azure, 51.6\% are familiar with Amazon Web Service, and 11.8\% are familiar with Google GCP. This shows that the respondents are conversant with cloud computing for e-learning and perfectly fit the requirement to answer the questionnaire. Similarly, the respondent's education level ranges from Bachelor's Degree with 25.8\%, Master's Degree with 64.0\%, and Doctorate with $10.2 \%$. These perhaps indicate that the respondents are experienced as well as provide adequate variance regarding their background.

\section{Test of Response Bias}

Non-response bias refers to the error anticipated by researchers while estimating a sample feature due to under-representation of survey respondents to non-response (Berg, 2002).). Nonetheless, according to Malhotra, Hall, Shaw \& Oppenheim (2006), the overall findings may be distorted due to respondent significant difference from the non-respondents with regards to attitude, behaviour, motivation, and demographics etc. This is also supported by the submission of Singer (2006, p. 641) "there is no minimum response rate below which a survey estimate is necessarily biased and, conversely, no response rate above which it is never biased" (Singer, 2006, p. 641). "However, no matter small the non-response, there is a possible bias which must be investigated" (Pearl \& Fairley, 1985; Sheikh, 1981). Hence, the reason for testing for the non-response bias using the independent sample t-test. The assessment focuses on the demographic variables such as the gender, level of education, position in the university, institution type, institution location, experience in managing e-learning, experience using cloud computing for e-learning purposes, familiarity with type IaaSBEL, as well as a number of students in the institution respectively.

\section{Coding}

Coding was performed to ease items identification as well as ascertain that all items have a unique identification code in SPSS. The unique number will be recorded in the questionnaire.

\section{Editing}

The questionnaire that was retrieved from the respondents were checked for errors (incompleteness). The ones found to be skipped were instantly and marked and rejected. Likewise, the questionnaires with more than $25 \%$ left un-attended were removed from the dataset. However, questions with fewer missing values were used and missing value (using the mean substitution technique).

\section{Missing Data}

To lessen the percentage of missing data, precautionary measures were observed, such as giving the questionnaire to the respondents and check for any missing/skipped question. Further, the researcher swiftly checks to see if there are any missing or answered are not answered correctly, to call the attention of the respondent. This way, missing data was significantly reduced. The most conventional method to deal with missing data is case deletion 
(Tabachnick \& Fidell, 2007). Deleting missing data is useful when the data is large. Nonetheless, there is no permissible threshold of missing data for making a valid statistical inference. However, Tabachnick and Fidell (2007) suggested that the missing value rate of $\leq$ $5 \%$ is non-significant, and thus one of the appropriate methods of missing data analysis is mean substitution. Therefore, this study adopts the mean substitution technique. Table 5 illustrates the summary of missing values in the data.

\begin{tabular}{ll}
\multicolumn{2}{c}{ Table 5: Percentage of Missing Values } \\
\hline Latent Variables & No. of Missing Values \\
\hline RA & 8 \\
COM & 1 \\
TR & 0 \\
SEC & 0 \\
TMS & 2 \\
CS & 5 \\
SPS & 0 \\
CP & 5 \\
INT & 1 \\
GS & 3 \\
Total & 25 out of 9,261 data points \\
Percentage & $0.26 \%$
\end{tabular}

\section{Assessment of Outliers}

Assessment of outliers is a significant step of data cleaning, which involves extreme case count, that may likely and negatively affect the result (Maiyaki \& Mouktar, 2011). Outliers are defined "in a set of data to be an observation (or subset of observations) which appears to be inconsistent with the remainder of that set of the data" (Barnett \& Lewis, 1978 p. 4). Thus, in "a regression analysis, the presence of outliers in the data set can seriously hamper the estimates of the regression coefficients, which will lead to distorted results" (Verardi \& Croux, 2008). This study identifies multivariate outlier's analysis using the Mahalanobis Distance method, a measure of the multivariate distance, which can be evaluated using the Chi-square $(X 2)$ table. The most common probability estimates for a "case being an outlier is $p<0.001$ for the $X 2$ value, is appropriate with Mahalanobis Distance" (Tabachnick \& Fidell, 2007). Hence, the Chi-Square table can also be used for the Mahalanobis based on the number of items. This study comprises of 49 items with Chi-Square value of $65.17(p=0.05)$. Therefore, any Mahalanobis value greater than 65.17 is discarded from the dataset. Therefore, no deletion was made because the highest Mahalanobis distance is 43.76, which is less than 65.17 thresholds.

\section{Normality Test}

Normality test is a crucial assumption in multivariate analysis (Hair et al., 2010). Screening continuous variables for normality is an essential early step in almost every multivariate analysis, although, the normality of the variables is not always required for analysis. Thus, normality of variables is assessed by either statistical or graphical methods (Tabachnick \& Fidell, 2007). The present study employs the statistical approach to assess the normality of collected data (Tabachnick \& Fidell, 2007). However, since the sample of this study is less than 200, the statistical method (Skewness and Kurtosis) will be adopted. 
Table 6: Normality Test Using Statistical Methods

\begin{tabular}{lll}
\hline Variable & Skewness & Kurtosis \\
\hline Relative Advantage (RA) & .295 & .200 \\
Compatibility (COM) & -1.206 & 3.114 \\
Trust (TR) & -.574 & -.083 \\
Security (SEC) & -.457 & -.146 \\
Top Management Commitment (TMC) & -1.300 & 2.987 \\
Cost Savings (CS) & -.726 & .437 \\
Competitive Pressure (CP) & -1.300 & 1.934 \\
Service Provider Support (SPS) & -.711 & .187 \\
Intention to Adopt IaaSBEL (INT) & -.254 & -.417 \\
Government Support (GS) & -1.335 & 1.350 \\
\hline
\end{tabular}

As depicted in Table 6, the values of Skewness fall between the range of -1.300 and .295 , where Kurtosis fall between 3.114 and -.417, which are considered to be approximately normally distributed according to Kline (2015). In addition, Kline (2015) stated that the absolute value of Skewness greater $>3$ and Kurtosis $>10$ indicates non-normality issues.

\section{Multicollinearity}

Multicollinearity refers to an issue that happens when the exogenous constructs are highly correlated with a value of 0.9 and above (Tabachnick \& Fidell, 2007). When a number of variables are too correlated, they tend to contain redundant information and therefore, increase and inflate the size of the error, which in turn weakens the analysis. One of the easiest ways of detecting the multicollinearity problem is resolved by deleting the affected variable(s). Additionally, to identify multicollinearity, Tolerance and Variance Inflation Factor (VIF) are utilised (Chatterjee \& Yilmaz, 1992; Peng \& Lai, 2012). The Tolerance value of $>0.10$ and VIF $<10$ are the thresholds recommended by Field (2009). Hence, Multicollinearity issues are not observed in the study, as shown in Table 7.

Table 7: Multicollinearity Analysis

\begin{tabular}{lll}
\hline Exogenous Variables & \multicolumn{2}{l}{ Collinearity } \\
\hline & Tolerance & VIF \\
Relative Advantage (RA) & .827 & 1.210 \\
Compatibility (COM) & .578 & 1.729 \\
Trust (TR) & .540 & 1.853 \\
Security (SEC) & .600 & 1.667 \\
Top Management Commitment (TMC) & .553 & 1.808 \\
Cost Savings (CS) & .635 & 1.574 \\
Competitive Pressure (CP) & .435 & 2.300 \\
Service Provider Support (SPS) & .607 & 1.647 \\
Government Support (GS) & .513 & 1.949 \\
\hline
\end{tabular}

\section{Exploratory Factor Analysis for Exogenous and Endogenous Variables}

All items were subjected to Principal Components Analysis (PCA) analysis using SPSS. Performing the PCA analysis is crucial, even though the measurement were adapted from preceding research. Nonetheless, in this research, the measures were used in a different context but were a little bit altered to suit the objectives of the study. The factor analysis was conducted to scrutinize the relationships between large numbers of items which enable researchers to 
classify them into smaller groups or factors (Hooper, 2012). Hence, the Exploratory Factor Analysis (EFA) is performed during the pilot study as the basis for construct development, particularly to identify the underlying construct behind a set of measured variables (Suhr, 2006). Thus, the EFA is suitable to perform using pilot data as a foundation for the Confirmatory Factor Analysis (CFA) in the actual study data.

As an alternative, this study runs EFA based on each construct. This is principally due to the items were selected from previous studies that measured the intended constructs. Hence, this study aims to prove the structure of these items. Similarly, Hair et al. (2010) "recommended the thresholds in conducting the EFA; Bartlett Test $<0.5$, Kaiser-Meyer-Olkin (KMO) $>0.8$, Factor Loading $\geq 0.5$, Communalities $\geq 0.3$, as well as Eigenvalue $\geq 1.0$ " respectively. However, KMO value greater than .5 is acceptable (Field, 2013; Kaiser, 1970). Therefore, all the items meet the Hair and Kaiser's recommendations (See Table 8).

Table 8: Multicollinearity Analysis

\begin{tabular}{|c|c|c|c|c|c|c|c|}
\hline VAR & KMO & $\begin{array}{l}\text { Eigen } \\
\text { Value }\end{array}$ & $\begin{array}{l}\text { Bartlett } \\
\text { Test }\end{array}$ & Item & $\begin{array}{l}\text { Factor } \\
\text { Loading }\end{array}$ & Communalities & $\begin{array}{l}\text { Deleted } \\
\text { Items }\end{array}$ \\
\hline \multirow[t]{6}{*}{ RA } & 0.691 & 4.055 & 0.000 & RA1 & 0.823 & 0.762 & Nil \\
\hline & & & & RA2 & 0.891 & 0.883 & Nil \\
\hline & & & & RA3 & 0.934 & 0.873 & Nil \\
\hline & & & & RA4 & 0.849 & 0.913 & Nil \\
\hline & & & & RA5 & 0.951 & 0.904 & Nil \\
\hline & & & & RA6 & 0.785 & 0.851 & Nil \\
\hline \multirow[t]{6}{*}{$\mathrm{COM}$} & 0.624 & 2.502 & 0.000 & COM1 & 0.771 & 0.611 & Nil \\
\hline & & & & COM2 & 0.899 & 0.813 & Nil \\
\hline & & & & COM3 & 0.744 & 0.829 & Nil \\
\hline & & & & COM4 & 0.834 & 0.702 & Nil \\
\hline & & & & COM5 & 0.520 & 0.719 & Nil \\
\hline & & & & COM6 & 0.807 & 0.663 & Nil \\
\hline \multirow[t]{3}{*}{ TR } & 0.692 & 2.115 & 0.000 & TR1 & 0.832 & 0.692 & Nil \\
\hline & & & & TR2 & 0.882 & 0.778 & Nil \\
\hline & & & & TR3 & 0.803 & 0.645 & Nil \\
\hline \multirow[t]{3}{*}{ SEC } & 0.621 & 2.119 & 0.000 & SEC1 & 0.911 & 0.829 & Nil \\
\hline & & & & SEC2 & 0.894 & 0.799 & Nil \\
\hline & & & & SEC4 & 0.701 & 0.491 & Nil \\
\hline \multirow[t]{6}{*}{ TMC } & 0.568 & 2.388 & 0.000 & TMC1 & 0.926 & 0.867 & Nil \\
\hline & & & & TMC2 & 0.843 & 0.748 & Nil \\
\hline & & & & TMC3 & 0.850 & 0.750 & Nil \\
\hline & & & & TMC4 & 0.799 & 0.798 & Nil \\
\hline & & & & TMC5 & 0.729 & 0.799 & Nil \\
\hline & & & & TMC6 & 0.911 & 0.873 & Nil \\
\hline \multirow[t]{4}{*}{ CS } & 0.789 & 3.032 & 0.000 & CS1 & 0.915 & 0.837 & Nil \\
\hline & & & & CS2 & 0.870 & 0.756 & Nil \\
\hline & & & & CS3 & 0.895 & 0.801 & Nil \\
\hline & & & & CS4 & 0.798 & 0.638 & Nil \\
\hline
\end{tabular}




\begin{tabular}{|c|c|c|c|c|c|c|c|}
\hline & & & & & & \multicolumn{2}{|c|}{$\begin{array}{l}\text { Journal of Information System } \\
\text { and Technology Management }\end{array}$} \\
\hline & & & & & & \multicolumn{2}{|c|}{ EISSN: 0128-1666 } \\
\hline & & & & & & \multicolumn{2}{|c|}{$\begin{array}{r}\text { Volume } 5 \text { Issue } 18 \text { (September 2020) PP. 01-18 } \\
\text { DOI: 10.35631/IISTM.518001 }\end{array}$} \\
\hline \multirow[t]{7}{*}{$\mathrm{CP}$} & 0.741 & 3.974 & 0.000 & CP1 & 0.731 & 0.665 & Nil \\
\hline & & & & $\mathrm{CP} 2$ & 0.761 & 0.923 & Nil \\
\hline & & & & CP3 & 0.793 & 0.836 & Nil \\
\hline & & & & $\mathrm{CP} 4$ & 0.943 & 0.897 & Nil \\
\hline & & & & CP5 & 0.921 & 0.857 & Nil \\
\hline & & & & CP6 & 0.803 & 0.753 & Nil \\
\hline & & & & $\mathrm{CP} 7$ & 0.637 & 0.755 & Nil \\
\hline \multirow[t]{7}{*}{ SPS } & 0.674 & 3.878 & 0.000 & SPS1 & 0.851 & 0.727 & Nil \\
\hline & & & & SPS2 & 0.556 & 0.386 & Nil \\
\hline & & & & SPS3 & 0.844 & 0.803 & Nil \\
\hline & & & & SPS4 & 0.903 & 0.817 & Nil \\
\hline & & & & SPS5 & 0.938 & 0.881 & Nil \\
\hline & & & & SPS6 & 0.580 & 0.522 & Nil \\
\hline & & & & SPS7 & 0.907 & 0.838 & Nil \\
\hline \multirow[t]{3}{*}{ INT } & 0.541 & 1.958 & 0.000 & INT1 & 0.658 & 0.434 & Nil \\
\hline & & & & INT2 & 0.916 & 0.838 & Nil \\
\hline & & & & INT3 & 0.828 & 0.686 & Nil \\
\hline \multirow[t]{4}{*}{ GS } & 0.790 & 3.283 & 0.000 & GS1 & 0.817 & 0.667 & Nil \\
\hline & & & & GS2 & 0.907 & 0.823 & Nil \\
\hline & & & & GS3 & 0.965 & 0.931 & Nil \\
\hline & & & & GS4 & 0.928 & 0.862 & Nil \\
\hline
\end{tabular}

\section{Discussion}

The preliminary analysis is an important step that must be performed before any test can be performed in a quantitative study. The data cleaning or noise reduction involves the steps and thresholds that research data must meet before it can be used for more rigorous statistical analysis. From the above sections, it can be noted that the research data undergo numerous data cleaning or noise reduction processes which include; descriptive statistics of respondents, response bias, missing data analysis, assessment of outliers, normality of data, multicollinearity and EFA using PCA. Following the steps listed above, the data was cleaned, and outliers were eliminated. Therefore, the research data met all statistical and multivariate assumptions for further analysis using PLS-SEM.

\section{Conclusion}

This study discusses the issues related to preliminary analysis and data cleaning in IS research. The findings revealed some missing data cases $(<5 \%)$, which were addressed using mean substitution as postulated by Hair et al. (2013). Similarly, the multivariate outliers and nonresponse bias were not an issue in this study. Data cleaning process were performed to ascertain the reliability of data. The data satisfy the primary assumption as well as the requirements for performing the multivariate analysis (Hair et al., 2010; Tabachnick \& Fidell, 2007). Besides, the convergence of divergent factors into the Technology, Organization and Environmental perspective show high factor loadings, ascertaining that the variables are measuring the intended constructs as theorized. Therefore, these findings will provide an insight to further 


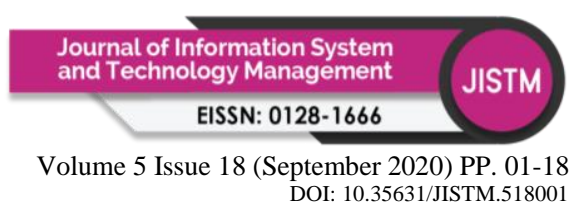

perform rigorous analysis as well as provide the understanding of how and why of the cloud computing studies in developing countries HEIs.

\section{References}

Alavi, M., \& Leidner, D. E. (2001). Research Commentary: Technology-Mediated Learning A Call for Greater Depth and Breadth of Research. Information Systems Research, 12(1), 1-10. https://doi.org/10.1287/isre.12.1.1.9720

Alhammadi, A., Stanier, C., \& Eardley, A. (2015). The Determinants of Cloud Computing Adoption in Saudi Arabia. Computer Science \& Information Technology (CS \& IT), 55-67. https://doi.org/DOI : 10.5121/csit.2015.51406

Almazroi, A. A., Shen, H., Teoh, K.-K., \& Babar, M. A. (2016). Cloud for e-Learning: Determinants of Its Adoption by University Students in a Developing Country. 2016 IEEE 13th International Conference on E-Business Engineering (ICEBE), 71-78. https://doi.org/10.1109/ICEBE.2016.022

Alreck, P. L., \& Settle, R. B. (1995). The survey research handbook (2nd ed.). Irwin Professional

Publishing. https://trove.nla.gov.au/work/11700610?q\&sort=holdings+desc\&_=1535472719144\& versionId $=45626555$

Ansong, E., Boateng, S. L., Boateng, R., \& Effah, J. (2016). Determinants of E-Learning Adoption in Universities: Evidence from a Developing Country. 2016 49th Hawaii International Conference on System Sciences (HICSS), 21-30. https://doi.org/10.1109/HICSS.2016.12

Barnett, V., \& Lewis, T. (1978). Outliers in Statistical Data (3rd editio).

Blythe, J. (2005). Essentials of Marketing (Third Edit). Prince Hall.

Chang, I.-C., Hwang, H.-G., Yen, D. C., \& Lian, J. W. (2006). Critical factors for adopting PACS in Taiwan: Views of radiology department directors. Decision Support Systems, 42(2), 1042-1053. https://doi.org/10.1016/J.DSS.2005.08.007

Chatterjee, S., \& Yilmaz, M. (1992). A Review of Regression Diagnostics for Behavioral Research. Applied Psychological Measurement, 16(3), 209-227. https://doi.org/10.1177/014662169201600301

Chiu, C.-Y., Chen, S., \& Chen, C.-L. (2017). An Integrated Perspective of TOE Framework and Innovation Diffusion in Broadband Mobile Applications Adoption by Enterprises. International Journal of Management, Economics and Social Sciences, 6(1), 14-39. http://ijmess.com/volumes/volume-VI-2017/issue-I-03-2017/full-2.pdf

Dahnil, M. I., Marzuki, K. M., Langgat, J., \& Fabeil, N. F. (2014). Factors Influencing SMEs Adoption of Social Media Marketing. Procedia - Social and Behavioral Sciences, 148, 119-126. https://doi.org/10.1016/J.SBSPRO.2014.07.025

Field, A. (2013). Discovering Statistics using IBM SPSS Statistics (4th ed.). SAGE. https://books.google.com.my/books?id=c0Wk9IuBmAoC\&dq=field+a.+(2009).+disc overing+statistics+using+spss+(4thed.)\&source=gbs_navlinks_s

Field, A. P. (2009). Discovering statistics using SPSSd rock " $n$ " roll) (3rd editioin). SAGE Publications.

Gupta, P., Seetharaman, A., \& Raj, J. R. (2013). The usage and adoption of cloud computing by small and medium businesses. International Journal of Information Management, 33(5), 861-874. https://doi.org/10.1016/j.ijinfomgt.2013.07.001

Hair, J. F., Black, W. C., Babin, B. J., \& Anderson, R. E. (2010). Multivariate Data Analysis (7th Edition). https://www.amazon.co.uk/Multivariate-Analysis-Seventh-BlackAnderson/dp/B003TXRJIQ 


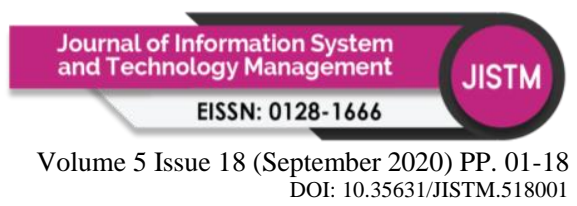

Hair, J. F. J., Black, W. C., Babin, B. J., \& Anderson, R. E. (2010). Multivariate Data Analysis (Seventh Ed). Pearson. https://www.pearson.com/us/higher-education/program/HairMultivariate-Data-Analysis-7th-Edition/PGM263675.html

Hair, J. F. J., Hult, G. T. M., Ringle, C., \& Sarstedt, M. (2013). A primer on partial least squares structural equation modeling (PLS-SEM) (2nd Edition). Sage. https://uk.sagepub.com/en-gb/asi/a-primer-on-partial-least-squares-structuralequation-modeling-pls-sem/book244583

Hair, J. J. F., Wolfinbarger, M. F., Ortinau, D. J., \& Bush, R. P. (2009). Essentials of Marketing Research. McGraw-Hill Irwin.

Hooper, D. (2012). Exploratory Factor Analysis Exploratory Factor Analysisin Chen, H. (Ed.), Approaches to Quantitative Research - Theory and its Practical Application: A Guide to Dissertation Students. Dublin Institute of Technology, 1-33. https://arrow.dit.ie/buschmanbk/8

Ifinedo, P. (2011). An Empirical Analysis of Factors Influencing Internet/E-Business Technologies Adoption By SMEs In Canada. International Journal of Information Technology \& Decision Making, 10(04), 731-766. https://doi.org/10.1142/S0219622011004543

Jarvenpaa, S. L., Tractinsky, N., \& Vitale, M. (2000). Consumer trust in an Internet store. Information Technology and Management, $1(1 / 2), \quad 45-71$. https://doi.org/10.1023/A:1019104520776

Kaiser, H. F. (1970). A SECOND GENERATION LITTLE JIFFY*. PSYCHOMETRIKA, $35(4), 401-415$.

Kline, R. B. (2015). principles and practice of structural equation modeling (Third). Guilford publications.

Klug, W., \& Bai, X. (2014). The Determinants of Cloud Computing Adoption by Colleges and Universities [Northcentral University]. https://search.proquest.com/docview/1527001253/previewPDF/D59DD1BB97F2419 APQ/1 ? accountid=42599

Lai, H.-M., Lin, I.-C., \& Tseng, L.-T. (2014). High-Level Managers' Considerations for RFID Adoption in Hospitals: An Empirical Study in Taiwan. Journal of Medical Systems, 38(2), 3. https://doi.org/10.1007/s10916-013-0003-z

Lee, S.-G., Hwang, S.-W., Kang, J.-Y., \& Yoon, S. (2014). Factors Influencing the Adoption of Enterprise Cloud Computing. Journal of Internet Technology, 15(1), 65-75. https://doi.org/10.6138/JIT.2014.15.1.07

Mahmoud, A. M., Ahmad, S. Bin, \& Poespowidjojo, A. L. D. (2018). The Relationship between Entrepreneurial Behavior, Psychological Factors and Individual Performance of Middle Managers in Nigerian Medium Enterprises: A Pilot Study. International Journal of Organization \& Business Execellence, 3(1), 1-17. http://www.ijobe.uum.edu.my/images/Full_Text/vol.3_issue.2_2018/IJOBE-31proofread.pdf

Maiyaki, A. A., \& Mouktar, S. S. M. (2011). Influence of service quality, corporate image and perceived value on customer behavioral responses in Nigerian Banks: Data screening and preliminary analysis. International Conference on Management Proceeding, 547568.

Mathieson, K. (1991). Predicting User Intentions: Comparing the Technology Acceptance Model with the Theory of Planned Behavior. Information Systems Research, 2(3), 173191. https://doi.org/10.2307/23010882 


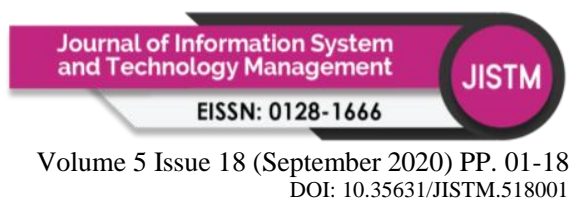

Mell, P., \& Grance, T. (2011). The NIST definition of cloud computing. http://faculty.winthrop.edu/domanm/csci411/Handouts/NIST.pdf

Mohammed, F., Alzahrani, A. I., Alfarraj, O., \& Ibrahim, O. (2018). Cloud Computing Fitness for E-Government Implementation: Importance-Performance Analysis. IEEE Access, 6, 1236-1248. https://doi.org/10.1109/ACCESS.2017.2778093

Moore, G. C., \& Benbasat, I. (1991). Development of an Instrument to Measure the Perceptions of Adopting an Information Technology Innovation. Information Systems Research, 2(3), 192-222. https://doi.org/10.1287/isre.2.3.192

Nguyen, T. D., Nguyen, T. M., Pham, Q.-T., \& Misra, S. (2014). Acceptance and Use of ELearning Based on Cloud Computing: The Role of Consumer Innovativeness. In International Conference on Computational Science and Its Applications (pp. 159174). Springer, Cham. https://doi.org/10.1007/978-3-319-09156-3_12

Odeh, M., Garcia-Perez, A., \& Warwick, K. (2017). Cloud computing adoption at higher education institutions in developing countries: a qualitative investigation of main enablers and barriers. International Journal of Information and Education Technology, 7(12), 921-927. https://doi.org/doi: 10.18178/ijiet.2017.7.12.996

Oliveira, T., Thomas, M., \& Espadanal, M. (2014). Assessing the determinants of cloud computing adoption: An analysis of the manufacturing and services sectors. Information \& Management, 51(5), 497-510. https://doi.org/10.1016/j.im.2014.03.006

Pavlou, P. A. (2003). Consumer Acceptance of Electronic Commerce: Integrating Trust and Risk with the Technology Acceptance Model. International Journal of Electronic Commerce, 7(3), 101-134. https://dl.acm.org/citation.cfm?id=1288221

Peng, D. X., \& Lai, F. (2012). Using partial least squares in operations management research: A practical guideline and summary of past research. Journal of Operations Management, 30(6), 467-480. https://doi.org/10.1016/j.jom.2012.06.002

Premkumar, G., \& Roberts, M. (1999). Adoption of new information technologies in rural small businesses. Omega, 27(4), 467-484. https://doi.org/10.1016/S03050483(98)00071-1

Rahm, Erhard, and H. H. D. (2000). "Data cleaning: Problems and current approaches." IEEE Data Eng. Bull., 23(4), 3-13.

Rogers, E. M. (1995). Diffusion of Innovations Third Edition (Third). Collier Macmillan Publishers. https://teddykw2.files.wordpress.com/2012/07/everett-m-rogers-diffusionof-innovations.pdf

Sabi, H. M., Uzoka, F.-M. E., Langmia, K., Njeh, F. N., \& Tsuma, C. K. (2017). A crosscountry model of contextual factors impacting cloud computing adoption at universities in sub-Saharan Africa. Information Systems Frontiers, 1-24. https://doi.org/10.1007/s10796-017-9739-1

Sabi, H. M., Uzoka, F.-M. E., \& Mlay, S. V. (2018). Staff perception towards cloud computing adoption at universities in a developing country. Education and Information Technologies, 23(5), 1825-1848.

Sekaran, U. (2003). Research Methods for Business: A Skill-Building Approach (4th Editio). ohn Wiley \& Sons.

Sekaran, Uma., \& Bougie, R. (2010). Research methods for business : A skill-building approach (5th, illustrated ed.). John Wiley \& Sons. https://books.google.com.my/books/about/Research_Methods_for_Business.html?id= a__YI3TJQuAC\&redir_esc $=y$

Shana, Z., \& Abulibdeh, E. (2017). Cloud Computing Issues for Higher Education: Theory of Acceptance Model. International Journal of Emerging Technologies in Learning 


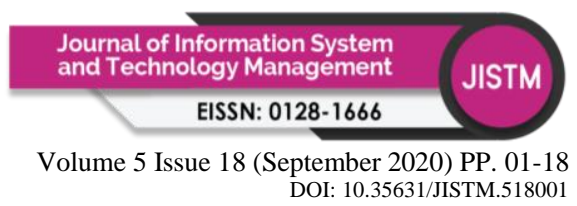

(IJET), 12(11), 168-184. http://journals.sfu.ca/onlinejour/index.php/ijet/article/view/7473

Suhr, D. D. (2006). Exploratory or Confirmatory Factor Analysis? Statistics and Data Analysis, $1-17$.

http://tx.liberal.ntu.edu.tw/ PurpleWoo/Literature/!DataAnalysis/FactorAnalysis_SA S.com_200-31.pdf

Tabachnick, B. G., \& Fidell, L. S. (2007). Using multivariate statistics (5th Edition). Pearson/Allyn \& Bacon. https://dl.acm.org/citation.cfm?id=1213888

Tariq, M. I., Tayyaba, S., Rasheed, H., \& Ashraf, M. W. (2017). Factors influencing the Cloud Computing adoption in Higher Education Institutions of Punjab, Pakistan. 2017 International Conference on Communication, Computing and Digital Systems (CCODE), 179-184. https://doi.org/10.1109/C-CODE.2017.7918925

Teo, T., Su Luan, W., \& Ching Sing, C. (2008). A cross-cultural examination of the intention to use technology between Singaporean and Malaysian pre-service teachers: an application of the Technology Acceptance Model (TAM). Educational Technology \& Society, 11(4), 265-280. https://www.j-ets.net/ETS/journals/11_4/19.pdf

Tom, A. M., Virgiyanti, W., \& Osman, W. R. S. (2019). The Impact of Government Support on the Adoption of IaaSBEL by University's Top Management. 2019 International Conference on Data and Software Engineering (ICoDSE), 1-6.

Tom, A. M., Virgiyanti, W., \& Rozaini, W. (2019). Understanding the Determinants of Infrastructure-as-a Service-Based E-Learning Adoption Using an Integrated TOE-DOI Model: A Nigerian Perspective. 2019 6th International Conference on Research and Innovation in Information Systems (ICRIIS), 1-6. https://doi.org/10.1109/ICRIIS48246.2019.9073418

Tornatzky, L. G., \& Fleischer, M. (1990). The processes of technological innovation. The Journal of Technology Transfer, 16(1), 45-46. https://doi.org/10.1007/BF02371446

Tweel, A. (2012). Examining the Relationship between Technological, Organizational, and Environmental Factors and Cloud Computing Adoption [Northcentral University (USA)]. In ProQuest Dissertations Publishing. https://search.proquest.com/docview/1101947090/abstract/EC45851E744B4920PQ/1 ?accountid=42599

Venkatesh, V., Thong, J. Y. L., \& Xu, X. (2012). Consumer acceptance and use of information technology: extending the unified theory of acceptance and use of technology. MIS Quarterly, 36(1), 157-178. https://s3.amazonaws.com/academia.edu.documents/36422124/Venkatesh_utaut2.pdf ?AWSAccessKeyId=AKIAIWOWYYGZ2Y53UL3A\&Expires $=1520260589 \&$ Signat ure $=$ ahQ\%2FKi\%2FGowB6OHQEsffBPoeN7UI\%3D\&response-contentdisposition=inline\%3B filename\%3DUnified_theory_of_accepta

Verardi, V., \& Croux, C. (2008). Robust Regression in Stata. SSRN Electronic Journal, 9(3), 493-453. https://doi.org/10.2139/ssrn.1369144

Wahsh, M. A., \& Dhillon, J. S. (2015). An investigation of factors affecting the adoption of cloud computing for E-government implementation. 2015 IEEE Student Conference on Research and Development (SCOReD), 323-328. https://doi.org/10.1109/SCORED.2015.7449349

Wang, Y.-M., Wang, Y.-S., \& Yang, Y.-F. (2010). Understanding the determinants of RFID adoption in the manufacturing industry. Technological Forecasting and Social Change, 803-815. https://doi.org/doi:10.1016/j.techfore.2010.03.006 
Volume 5 Issue 18 (September 2020) PP. 01-18 DOI: $10.35631 /$ JISTM.518001

Wu, W.-W. (2011). Developing an explorative model for SaaS adoption. Expert Systems with Applications, 38(12), 15057-15064. https://doi.org/10.1016/J.ESWA.2011.05.039

Zhu, K., \& Kraemer, K. L. (2005). Post-Adoption Variations in Usage and Value of E-Business by Organizations: Cross-Country Evidence from the Retail Industry. Information Systems Research, 16(1), 61-84. https://doi.org/10.1287/isre.1050.0045 